\title{
Development of Entrepreneurship Scale Towards University Students
}

\section{Desarrollo de la escala de emprendimiento hacia estudiantes universitarios}

\author{
${ }^{1}$ Near East University \\ ${ }^{2}$ Near East University
}

Özdem Nurluöz ${ }^{1}$, Samin Esmailzadeh ${ }^{2}$

Enviado: 27 de junio de 2019

Aceptado para publicar: 30 de julio de 2019

Publicado: 8 de agosto de 2019

\section{abstract}

The aim of this study is to develop a reliable and valid measurement tool to evaluate the entrepreneurship characteristics of university students. The study group is comprised of 386 students at the Faculty of Nursing, Near East University. Exploratory Factor Analysis (EFA) and Confirmatory Factor Analysis (CFA) were applied in order to assess the construct validity of entrepreneurship scale. Prior to the application of Exploratory Factor analysis, Kolmogrov Smirnov, Shapiro Wilks tests were applied in order to identify whether the data set shows normal distribution; QQ plot was analysed with regard to the distribution and the skewness and kurtosis values of distribution were checked accordingly. In consideration with the generated results, the data set was considered as showing normal distribution. Upon ensuring the normality assumption required for the Exploratory Factor analysis, Kaiser-Mayer-Olkin (KMO) coefficient and Barlett sphericity test that are used in the identification of data eligibility for the Exploratory Factor Analysis were applied respectively. The findings with regard to the reliability of scale were ensured with Cronbach Alpha (internal consistency). The findings showed that the reliability coefficient for internal consistency is sufficient. It is concluded that our study can be used in scientific researches since it was checked in terms of validity and reliability.

Keywords: Validity, Reliability, Scale Development, Entrepreneurship.

El objetivo de este estudio es desarrollar una herramienta de medición confiable y válida para evaluar las características empresariales de los estudiantes universitarios. El grupo de estudio está compuesto por 386 estudiantes de la Facultad de Enfermería de la Universidad del Cercano Oriente. El análisis factorial exploratorio (EFA) y el análisis factorial confirmatorio (CFA) se aplicaron para evaluar la validez de constructo de la escala de emprendimiento. Antes de la aplicación del análisis factorial exploratorio, se aplicaron las pruebas de Kolmogrov Smirnov y Shapiro Wilks para identificar si el conjunto de datos muestra una distribución normal; La gráfica QQ se analizó con respecto a la distribución y los valores de distribución de asimetría y curtosis se verificaron en consecuencia. En consideración con los resultados generados, se consideró que el conjunto de datos mostraba una distribución normal. Al garantizar la suposición de normalidad requerida para el análisis del Factor Exploratorio, se aplicaron el coeficiente de Kaiser-Mayer-Olkin (KMO) y la prueba de esfericidad de Barlett que se utilizan en la identificación de los datos elegibles para el Análisis del Factor Exploratorio, respectivamente. Los resultados con respecto a la confiabilidad de la escala se aseguraron con Cronbach Alpha (consistencia interna). Los resultados mostraron que el coeficiente de confiabilidad para la consistencia interna es suficiente. Se concluye que nuestro estudio puede usarse en investigaciones científicas ya que se verificó en términos de validez y confiabilidad.

Palabras clave: validez, confiabilidad, desarrollo de escala, emprendimiento. 


\section{Introduction}

Entrepreneurship is one of the significant and emphasized topics of existing century. Particularly scientists working at universities have major responsibilities in ensuring that students are aware of such quality and creating significant opportunities to develop their future vision. Pursuant to the study of Demirel and T1k1c1,2010:222, it is emphasized that "the studies regarding the evaluation of entrepreneurship characteristics of university students as potential entrepreneur candidates might contribute on the establishment of plans for their future business life, provision of theoretical knowledge about entrepreneurship and making a courageous step in going towards entrepreneurship".

\section{Initiative and Concept of Entrepreneurship}

Entrepreneurs are the people that foresee the future with regard to the improvement and development of country, bear a mission and become pioneers in the development of country and society through taking risks.Kılıç, R. et.al (2012) emphasized that the guidance of people with entrepreneur characteristics into entrepreneurship and increasing the number of entrepreneurs are important in the development of societies and achievement of sustainable competitive advantage.

The concept of entrepreneur is defined differently based on different professions. According to the economists, an entrepreneur is a person that produces and earns income with the condition of using the production resources efficiently. While the concept of entrepreneur means a courageous investor, ambitious and passionate competitor, client or partner; it means a person that invests, takes risks and earns income through competition for a business man (Singh \& Singha, 2016; Yazdekhasti et al, 2015).

According to the study of Yilmaz and Sümbül(2000:2), a psychologist defines an entrepreneur as a person "with high motivation that desires to own, accomplish and try something, and share the power of others". Entrepreneurs might be successful or unsuccessful, and we can evaluate such outcome at the end of their work. We have already indicated that successful entrepreneurs have a number of characteristics. Hisrich and Peters (1973) explained the personal characteristics of successful entrepreneurs as follows: Creative thinking skills that have the desire to work at high level, courage, passion and determination, ability to have high-level communication with people, ability to express themselves in a written and oral manner, sympathetic and humoristic, high level ability to persuade and convince people, love what they do and high level of work motivation, generous subconscious and imagination, prone to team work, open to change and transformation due to personal vision and mission, ability to behave with flexible tolerance, sincere, reliable, ability to manage and leadership, determination and excitement to complete a task, ability to foresee the future due to vision and habit to catch the opportunities (Yılmaz \& Sümbül,2009; Mostafavi et al, 2019; Amanlou \& Mostafavi, 2017).

In the literature, various authors defined the concept of entrepreneur differently. Considering all of the definitions, there is a consensus that entrepreneurship is about working towards utilising the opportunities in hand. Pursuant to the definition ofHisrich (1989), the entrepreneurship is the process of valuable awareness created with time and effort and the prediction of associated financial, psychological and social risks, and the financial, awarding and personal satisfaction.

The following are some examples regarding the definition of entrepreneurship under foreign resources (Merkibayev et al, 2018; Antúnez, 2016).

While Stevenson \& Sahlman (1989) explains it as the pursue of individuals towards other opportunities other that the existing resources in hand; Shane \& Venkataraman( 2000) defines the entrepreneurship as the correlation between the existence of profitable opportunities and entrepreneur individuals.

In the following years, Robert D. Hisrich \& Peters, 1998; Kinicki, (2003) defined entrepreneurship as the process for the occurrence of new matters and the prediction of risk and benefits.

In consideration with the definition of entrepreneurship noted in the past,Cantillon (1755) defined it as the self-recruitment in any task. Kirzner (1973) explained entrepreneurship as the ability to accurately predict the potential deficiencies and imbalances in the market while Ronstadt (1984) noted it as the dynamic process of already established and progressing opportunities. Stevenson, Roberts, \&Gousbeck (1985) defined the entrepreneurship in the way that individuals pursue the opportunities other than the resources that they control have within their own or any organisation.

The word of entrepreneur is derived from the French word of 'entreprendre', which means set out to (Lordkipanidze et.al, 2005; Muhammad, 2018). The first known definition for the concept of entrepreneur is the definition by Richard Cantillon made in the early $18^{\text {th }}$ century. Under the work of "Essai sur la nature du commerce en general" published in 1755, Cantillon focused on the risk taking characteristic of entrepreneur. Additionally, Jean Baptiste Say, a French economist, used the concept of entrepreneur. Say improved the definition of Cantillon and 
concentrated on the framework that "an entrepreneur should have qualities of organising the production factors and management in addition to undertaking risks" (Hisrich \&Peters, 1995; Kashisaz \& Mobarak, 2018).

Examples of Studies Conducted on the Factors that Affect the Entrepreneurship Potentials of University Students and Associated Results:

Under the studies conducted regarding the entrepreneurship, it is argued that the entrepreneurship characteristics are inherent, and it is known that the worldview and some personal characteristics change due to the education of an individual obtained throughout the life struggle. The work conditions and encountered opportunities allow the improvement of entrepreneurship characteristics and nurture the ideas of making other initiatives. Considering a part of such studies, the significance of developing a scale becomes more concrete.

According to Wickham (2006:103), the factors that hinder entrepreneurship are the challenges in establishing business and finding capital, high costs, risks deriving from the business environment, legal limitations, lack of entrepreneurship education, lack of complete and accurate understanding of entrepreneur image, challenges and limitations in human resources and personal qualities.

Örücü, Kılıç and Yılmaz (2007:30) emphasized that a number of factors such as family, friends, environment and technology are effective in the appearance of such skills. The trainings about entrepreneurship aim to provide knowledge to individuals that entrepreneurship is an adequately attractive option, and to enhance the motivation of entrepreneur candidates while providing required knowledge and skills (Balaban \& Özdemir 2008; Najibah, 2017).

While Negiz et.al, (2009:256) indicate that all components through socio-psychology, physiology and heritage influence the entrepreneurship,Doğaner and Altunoğlu (2010:104) noted that education has a major role in the entrepreneurship tendency of young population.

The study by Patır and Karahan (2010) called "Entrepreneurship Education and Determination of Entrepreneurship Profiles of University Students" concluded that the entrepreneurship infrastructure of university students is sufficient and the students with entrepreneurship education have more tendencies to open their own business.

Demirel and Tikici (2010) performed a significant study on the subject matter and reached vital results. Pursuant to the study called "Evaluation of Entrepreneurship Characteristics of University Students Using Brain Dominance Analysis", the right-brain functions of students are more powerful than the left-brain functions. The findings from the same study concluded, "the right-brain functions are more effective than the left-brain functions in the creation and development of entrepreneurship characteristics".

\section{Scale Development Process}

a)Evaluation of benefits through using the scale generated as a result of study performed by others:There are some advantages to prefer using an existing scale by getting the consent of its owner rather than developing a new scale. The most important advantage is that it would require less time and low cost.

Another advantage is derived where the expertise is insufficient in developing a scale within a second culture. Under such insufficiency circumstances, adaptation is more logical option rather than developing a new scale, and where the existing scale is well known, the confidence towards such scale in case of adaptation would be higher than the new scale.

b) Development of new scale: The first step in the planning of scale development is to collect theoretical data with regard to the entrepreneurship, and to create a pool with many items. The first step was to make literature review. In doing so, the emphasis was on the identification of questions that would take into consideration for the scale.

It is important to emphasize that the researchers had the feeling of necessity for developing a new scale, and the works performed during the scale development process started with the literature review are long-term.

With regard to the entrepreneurship, we used an existing scale by getting the consent of owner for the scientific research conducted among the students of Near East University Faculty of Nursing and Near East University Training and Research Hospital located in the Turkish Republic of Northern Cyprus. During the execution of such studies, we understood the importance of developing a new scale better for the future studies. We then started to find out what is necessary in order to develop a new scale since for any future study; the entrepreneurship scale would be the owner of researcher.We analysed a number of scientific study regarding scale development. The study gained momentum upon obtaining the required authorizations (Al-Khalifah, 2018; Shamsipur et al, 2012; Mostafavi et al, 2017).

A format was determined for the format of scale, and a pool comprised of items and questions were developed. During the design of items, having simple and understandable items without more than one judgment and opinion was taken into consideration.

The items that might require personal information of participants, which they might avoid sharing were placed in the further parts of scale, and the 
reason of doing this is to avoid unwillingness for the completion of scale. Therefore, it was decided that such questions should be placed in the further parts of scale.

c) The next phase was to consult professionalsin order to analyse the items upon the creation of item pool. The professionals were required to guide us with regard to the items by evaluating the necessity, clarity and specificity. It was proceeded by knowing that the professionals would recommend to take out or change some statements. It was ensured that the scope and outlook validity are analysed through professional opinion. The scale shaped in accordance with the professional opinion was applied on the draft sample group. It was proceeded with the knowledge that the trial provides significant values regarding the scale performance. The consideration was given towards the representation of sample on target group. Upon the trial, the validity and reliability analyses of scale were performed and the scale was finalized accordingly.

\section{Concepts of Validity and Reliability; Validity:}

Validity;Ercan İ, Kan İ (2004) defined the validity as the accurate measurement level of a measurement tool on the characteristic to be measured without confusing with any other characteristic, and emphasized that the validity in general is the service provision level of measurement tool within its purpose, and the validity of measurement might vary based on the purposes of measurements derived from measurement tools, and even the group that is applied and mode of application (Ercan İ, Kan İ 2004). Tavşanc1l $\mathrm{E}(2002)$ stated that the factors that deteriorate the validity are related with the scale development and implementation. Pursuant to the statement ofErcan İ, Kan I (2004), the validity coefficient is considered as the correlation coefficient between the values generated from the scale and criteria identified in accordance with the purpose in using the scale, and the values are between $-1+1.00$ and the higher correlation coefficient means better service for the purpose of scale.

\section{Reliability}

The reliability of a measurement tool is defined with the consistency in the measurement of variable or the level in the measurement results having no errors (Tavşancil E 2002, Arıkan R. 2011). The reliability is the stability of measurement value generated in the measurements conducted again with a measurement tool under the same circumstances and the indicator of reaching same value. The reliability is not only related with the measurement tool but also a feature that covers the measurement tool and its associated results
(Ercan İ, Kan İ 2004). Therefore, it would be more appropriate to define it as measurement reliability for the reliability of test or measurement tool (Bademci V.2006).

\section{There are 3 concepts under the reliability as} given below:

1. Consistency: Consistencymeans the coherence of items (questions) within a measurement tool with the whole test.

2. Stability: Stability means to obtain the same results in the characteristic as the subject matter of measurement when retested a couple of times with the same measurement tool at different times.

3. Sensitivity: Sensitivity is related with the size of measurement tool or unit of result. Where the unit range is small, then the measurement has more sensitivity (Atılgan H 2006).

\section{Method}

The aim of this study is to develop a reliable and valid measurement tool that would measure the entrepreneurship of university students. Therefore, this study is considered as diagnostic type basic research. A convenience sampling method was utilised for this research. Erkuş (2009) defined the convenience sampling as the sampling performed on individuals in the close environment, who are easy to access and voluntary.

Research group: This research was conducted on a total number of 386 university students from the Faculty of Nursing at the Near East University. Among such 386 students, 226 are female and 160 are male.

Statistical Analysis of Data: SPSS 21.0 and AMOS 21.0 were used in the data analysis. The factor structure of scale was analysed with Exploratory Factor Analysis (EFA) and Confirmatory Factor Analysis (CFA) while the reliability is evaluated with Cronbach Alpha and Split Half test.

\section{Findings}

\section{Construct Validity}

The Exploratory Factor Analysis (EFA) and Confirmatory Factor Analysis (CFA) were used in order to evaluate the construct validity of Entrepreneurship Scale.

\section{Exploratory Factor Analysis}

Firstly, the Exploratory Factor Analysis (EFA) was used in order to reflect the factor structure of Entrepreneurship Scale.Upon the data generated from the field, the Exploratory Factor Analysis is used to determine whether the theoretical correlations between the variables generated from the observed measurements or concepts that are assumed to be measured by the components in the 
scales comprised of a number of items measure such structure or concept in reality, and most importantly to identify the independent factors that constitute this structure (Büyüköztürk, 2002). Prior to the application of Exploratory Factor analysis, Kolmogrov Smirnov, Shapiro Wilks tests were applied in order to identify whether the data set shows normal distribution; QQ plot was analysed with regard to the distribution and the skewness and kurtosis values of distribution were checked accordingly. In consideration with the generated results, the data set was considered as showing normal distribution.
Upon ensuring the normality assumption required for the Exploratory Factor analysis, KaiserMayer-Olkin (KMO) coefficient and Barlett sphericity test that are used in the identification of data eligibility for the Exploratory Factor Analysis were applied respectively. KMO coefficient provides information whether the data matrix is eligible for factor analysis and data structure can generate factor. KMO should be more than 0,60 for factorability. Barlett test analyses the availability of correlation between variables based on the partial correlations (Büyüköztürk, 2009).

Table 3.1. Results of KMO and Bartlett's sphericity test

\begin{tabular}{lll}
\hline Kaiser-Meyer-Olkin Coefficient & & 0,786 \\
\hline & Approx. ${ }^{2}$ & 1766,371 \\
Bartlett's sphericity test & $\mathrm{sd}$ & 253 \\
& $\mathrm{p}$ & $0,000^{*}$ \\
\hline
\end{tabular}

$* p<0,05$

In consideration with the results given under Table 3.1, KMO coefficient of scale was found as 0,786 , which is above 0,60 as the recommended value. Following the Barlett's sphericity test, the estimated chi square value of scale was calculated as 1766,371 , which can be considered as statistically significant.

Upon the results of KMO and Bartlett's sphericity test, the data set was concluded as eligible for factor analysis.

The principal components analysis method was utilised in the performance of exploratory factor analysis on the entrepreneurship scale, and varimax rotation was applied on the data accordingly.

Table 3.2. EFA Results of Entrepreneurship Scale

\begin{tabular}{lllllll}
\hline \multirow{2}{*}{ Factor } & \multicolumn{2}{c}{ Initial Eigenvalue } & \multicolumn{4}{c}{ Sum of squares } \\
& Total & \% Var. & Cum. \% & Tot. & \% Var. & Cum. \% \\
\hline $\mathbf{1}$ & 11,923 & 51,841 & 51,841 & 11,923 & 51,841 & 51,841 \\
\hline
\end{tabular}

Considering the values under Table 3.2, there is one factor under the Entrepreneurship Scale with the eigenvalue higher than 1 . The single factoral structure of scale with the eigenvalue of 11,923 explains $51,841 \%$ of total variance, and the factor loadings of propositions given under the scale vary between 0,53 and 0,72 . As a result of AFA, 17 items were removed from the draft Entrepreneurship scale form, which used to have 40 items, and the form with 23 items were shaped respectively.

Confirmatory Factor Analysis

Confirmatory factor analysis was applied in order to ensure the construct validity of scale based on the findings generated as a result of exploratory factor analysis. Confirmatory Factor Analysis is a factor analysis utilised to test the eligibility of factor determined through the Exploratory Factor Analysis with the factor structures identified with hypothesis. While exploratory factor analysis is used to identify the variable groups and factor that have high-level correlation; CFA isused to identify whether the variable groups that contribute on the certain $\mathrm{k}$ number of factors are represented with such factors sufficiently (Aytaç and Öngen, 2012).

Table 3.3. CFA Goodness of Fit Values of Entrepreneurship Scale

Goodness of Fit Index

$\chi^{2} / \mathrm{sd}$ (chi square / degree of freedom)

Root Mean Square Error of Approximation (RMSEA)

Normed Fit Index (NFI)
Value

2,061

0,053

0,902 
In consideration with the goodness of fit results regarding the model established for the Entrepreneurship Scale under Table $3.4, \chi^{2} / \mathrm{sd}$ value was found as 2,061, Root Mean Square Error of Approximation (RMSEA) as 0,053, Normed Fit Index (NFI) as 0,902, Comparative Fit Index (CFI) as 0,935 , Goodness of Fit Index (GFI) as 0,933 andAdjusted Goodness of Fit Index (AGFI)as 0,911 . The value for $\chi^{2} / \mathrm{sd}$ under 3 shows perfect fit, while the value between 3 and 5 shows acceptable fit(Kline, 2005). Since the Root Mean Square Error of Approximation (RMSEA) is found between $0,05-0,08$, which is the range considered as acceptable fit, the model is determined as having an acceptable fit in terms of RMSEA. The critical value specified for the Normed Fit Index (NFI) and Comparative Fit Index (CFI) is between 0,90 and 1,00, which shows the existence of good fit (Tabachnick and Fidell, 2001). The value for GFI to be above 0.90 reflects a good fit with regard to the model (Ayyildiz and Cengiz, 2006). Therefore, the Entrepreneurship Scale has a perfect fit in terms of $\chi^{2} / \mathrm{sd}$ (chi square / degree of freedom), and an acceptable fit with regard to RMSEA, NFI, CFI, GFI and AGFI.

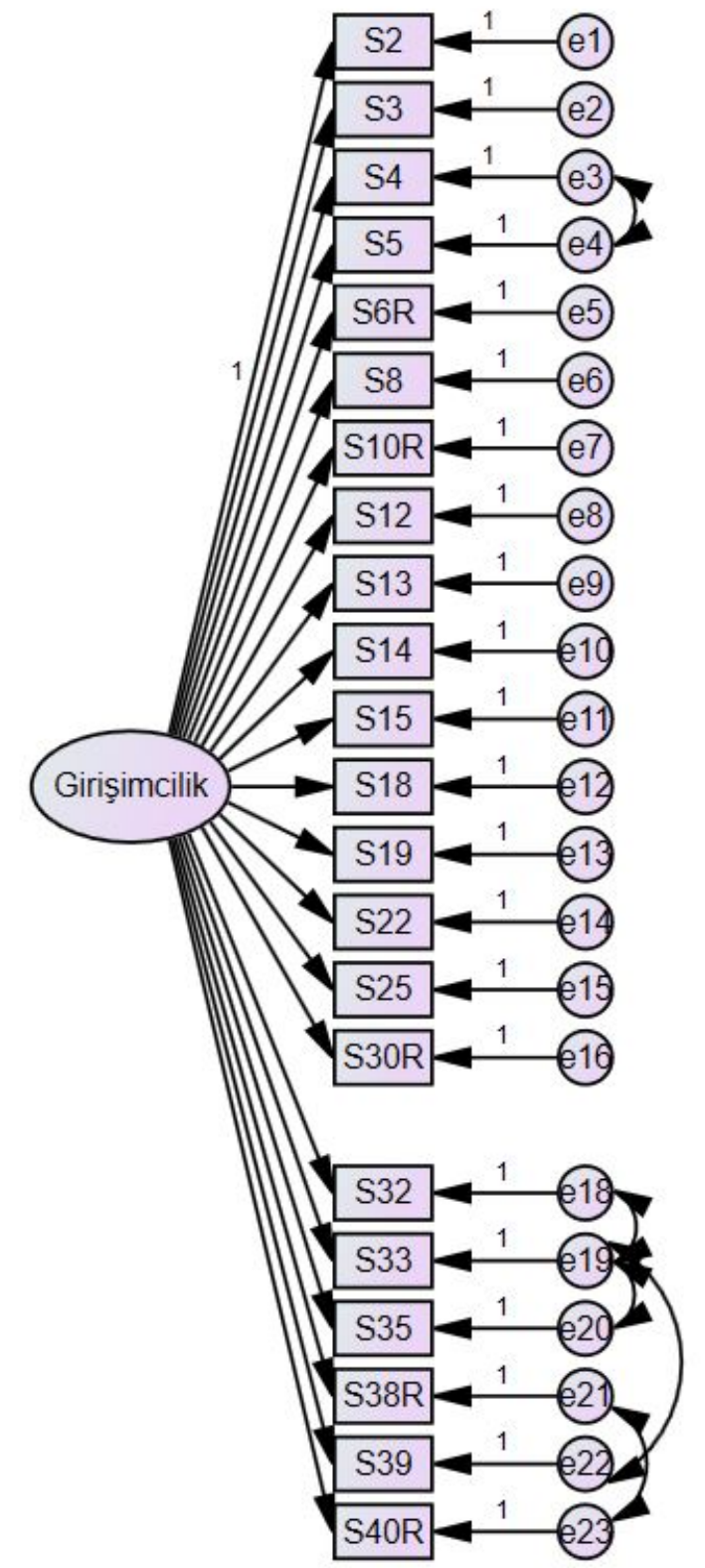

Figure 1.Path analysis results of Entrepreneurship Scale

Upon the confirmatory factor analysis, another one item was removed from the scale and the construct validity was ensured as 22 items.

\section{Reliability}

Following the construct validity of Entrepreneurship Scale, reliability analyses were conducted in order to evaluate whether the scale is a reliable measurement tool.

Table 3.4. Cronbach's Alpha Test Results of Entrepreneurship Scale 


\begin{tabular}{|c|c|c|c|}
\hline & & & Values \\
\hline Cronbach's Alpha Coefficient & & & 0,787 \\
\hline \multirow{4}{*}{$\begin{array}{l}\text { Cronbach's Alpha } \\
\text { Coefficient }\end{array}$} & \multirow{2}{*}{ Part 1} & Value & 0,760 \\
\hline & & Item No. & 11 \\
\hline & \multirow{2}{*}{ Part 2} & Value & 0,722 \\
\hline & & Item No. & 11 \\
\hline Correlation between parts & & & 0,540 \\
\hline Spearman-Brown Coefficient & & & 0,711 \\
\hline Guttman Split-Half Coefficient & & & 0,711 \\
\hline
\end{tabular}

Firstly, the Cronbach's Alpha Test was applied in order to identify the internal consistency of Entrepreneurship Scale and the Cronbach's Alpha value was calculated as 0,787 . Additionally, the split half test was performed on the scale and pursuant to its results, the Cronbach's Alpha value for the first part that is comprised of 11 items were find as 0,760 and for the second part with 11 items as 0,722 . The correlation coefficient between the parts was found as 0,540 and the SpearmanBrownandGuttman Split-Half Coefficientwas found as 0,711. According toBüyüköztürk (2012), the measurement tool is considered as reliable where the alpha reliability coefficient is above 0,70 . Hence, the alpha value regarding the whole scale is identified as high, which indicates reliability for the measurement tool.

In addition to the Cronbach's alpha and split half tests, the item-total correlation was analysed and the total number of items under the scale and their coefficients was found as varying between 0,371 0,642 .

c) Cronbach's Alpha Reliability Coefficient: The Cronbach's alpha coefficient is a weighted standard variation mean calculated through proportioning the variance total of $\mathrm{k}$ item under the scale with the general variance (Ercan İ, Kan İ 2004). The alpha coefficient methodology was developed by Cronbach back in 1951, and there are some opinions that it is an internal consistency estimation method that is suitable to use where the items are not scored as right-wrong but as 1-3, 1$4,1-5$, and also other opinions, which argue that it is possible to use in dichotomous cases (Bademci $\mathrm{V}$ 2006). The generally accepted value for the calculated coefficient is at least 0,70 .

\section{Conclusion and Discussion}

From the perspective of science, the measurement means all activities conducted in order to obtain a level of clarity in understanding the measured fact.

The aim of measurement is to establish an absolute judgment without feeling any contradiction during the interpretation. Within the framework of science, the objective of science is to reveal a certain concrete conceptual structure and reflect the change or correlation within the facts clearly in order to reach a scientific outcome. The generalizability of measurement tool (standardisation) is observed with the correct measurement of the fact that it is aimed to measure, and by reaching the same results from the recurrent measurements.

In order to reach a concrete decision under scientific researches, the generalizable scale with proved reliability and validity, and the data generated with the measurement tools should be tested.

This study aimed to design items that can measure entrepreneurship with the purpose of developing the scale by the researchers for the performance of Validity and Reliability checks of the Entrepreneurship Scale Towards University Students following a literature review. Upon this phase under the scale, the professionals were consulted accordingly.

After the consultation with professionals, a total number of 100 students were asked to fill in the scale. The next step was the construct validity in scale development where Exploratory Factor Analysis (EFA) and Confirmatory Factor Analysis (CFA) were used to analyse the construct validity of Entrepreneurship Scale.

\section{Exploratory Factor Analysis}

Prior to the application of Exploratory Factor analysis, Kolmogrov Smirnov, Shapiro Wilks tests were applied in order to identify whether the data set shows normal distribution; QQ plot was analysed with regard to the distribution and the skewness and kurtosis values of distribution were checked accordingly. In consideration with the generated results, the data set was considered as showing normal distribution.

In consideration with the results given under Table 3.1, KMO coefficient of scale was found as 0,786 , which is above 0,60 as the recommended value. Following the Barlett's sphericity test, the estimated chi square value of scale was calculated as 1766,371 , which can be considered as statistically significant.

Firstly, the Cronbach's Alpha Test was applied in order to identify the internal consistency of Entrepreneurship Scale and the Cronbach's Alpha 
value was calculated as 0,787 . Additionally, the split half test was performed on the scale and pursuant to its results, the Cronbach's Alpha value for the first part that is comprised of 11 items were find as 0,760 and for the second part with 11 items as 0,722 . The correlation coefficient between the parts was found as 0,540 and the SpearmanBrownandGuttman Split-Half Coefficientwas found as 0,711. According to Büyüköztürk (2012), the measurement tool is considered as reliable where the alpha reliability coefficient is above 0,70 . Hence, the alpha value regarding the whole scale is identified as high, which indicates reliability for the measurement tool.

Upon the results of KMO and Bartlett's sphericity test, the data set was concluded as eligible for factor analysis.

The principal components analysis method was utilised in the performance of exploratory factor analysis on the entrepreneurship scale, and varimax rotation was applied on the data accordingly.

Considering the values under Table 3.2, there is one factor under the Entrepreneurship Scale with the eigenvalue higher than 1 . The single factoral structure of scale with the eigenvalue of 11,923 explains $51,841 \%$ of total variance, and the factor loadings of propositions given under the scale vary between 0,53 and 0,72 . As a result of AFA, 17 items were removed from the draft Entrepreneurship scale form, which used to have 40 items, and the form with 23 items were shaped respectively.

\section{Confirmatory Factor Analysis}

Confirmatory factor analysis was applied in order to ensure the construct validity of scale based on the findings generated as a result of exploratory factor analysis. Confirmatory Factor Analysis is a factor analysis utilised to test the eligibility of factor determined through the Exploratory Factor Analysis with the factor structures identified with hypothesis.

In consideration with the goodness of fit results regarding the model established for the Entrepreneurship Scale under Table $3.4, \chi^{2} / \mathrm{sd}$ value was found as 2,061, Root Mean Square Error of Approximation (RMSEA) as 0,053, Normed Fit Index (NFI) as 0,902,Comparative Fit Index (CFI) as 0,935 , Goodness of Fit Index (GFI) as 0,933 andAdjusted Goodness of Fit Index (AGFI) as 0,911 . The value for $\chi^{2} /$ sd under 3 shows perfect fit, while the value between 3 and 5 shows acceptable fit(Kline, 2005). Since the Root Mean Square Error of Approximation (RMSEA) is found between $0,05-0,08$, which is the range considered as acceptable fit, the model is determined as having an acceptable fit in terms of RMSEA. The critical value specified for the Normed Fit Index (NFI) and Comparative Fit
Index (CFI) is between 0,90 and 1,00 , which shows the existence of good fit (Tabachnick and Fidell, 2001). The value for GFI to be above 0.90 reflects a good fit with regard to the model (Ayyıldız and Cengiz, 2006). Therefore, the Entrepreneurship Scale has a perfect fit in terms of $\chi^{2} / \mathrm{sd}$ (chi square / degree of freedom), and an acceptable fit with regard to RMSEA, NFI, CFI, GFI and AGFI.

\section{Recommendations}

The significance of scales is major in scientific research particularly quantitative studies. The use of scales generated under different scales would lead richness in scientific studies. Therefore, the development and introduction of new scales in every domain would facilitate the performance of many studies and also contribute to the science.

The development of scale would pioneer many people in other studies as a result of ensuring reliability and validity. Therefore, the individuals that conduct scientific studies in this subject matter should be encouraged to develop scales respectively.

The university students should also be encouraged to develop new scales that would ensure the performance of scientific studies in various topics. Similarly, the universities should encourage the lecturers and their students regarding the development of new scales.

\section{References}

Akgül A. Trbbi Araştırmalarda İstatistiksel Analiz Teknikleri. Ankara: Emek ofset, 2003, 2. Basım, 17. Bölüm:440-54.

Al-Khalifah, A., The Strategic Stabilization of Private Banks and Insurance Company in the Financial Service Sector. Journal of Humanities Insights, 2018. 02(04): p. 161166.

Amanlou, M. and S.M. Mostafavi, In sillico screening to aim computational efficient inhibitors of caspase-9 by ligand-based pharmacophore modeling. Medbiotech Journal, 2017. 01(01): p. 34-41.

Antúnez, J. V. V. (2016). Ciencia y Tecnología para la libertad. Opción, 32(79), 7-9.

Arıkan R. Araștırma Yöntem ve Teknikleri. Nobel yayınevì,2011,1. Basım, bölüm 6:937.

Atılgan H. Eğitimde Ölçme ve Değerlendirme. Ankara:Anıl yayıncılık, 2006, Bölüm1-3:1 131.

Aytaç, M., \& Öngen, B. (2012). Doğrulayıcı faktör analizi ile Yeni Cevresel Paradigma Ôlçeğinin yap1 geçerliliğinin incelenmesi. İstatistikçiler Dergisi, 5, 14-22

Ayyıldız, H.ve Cengiz, E. (2006), Pazarlama Modellerinin Testinde Kullanilabilecek 
Yapısal Essitlik Modeli Üzerine Kavramsal Bir İnceleme, Süleymen Demirel Üniversitesi İ̉BF, C.11,S.1 s.63-84

Bademci V. Tartısmayı Sonlandirmak: Crronbach'ın Alfa Katsayıs1, Iki Değerli Ölçümlenmis Maddeler ile Kullanılabilir. Kazım Karabekir Eğitim Fakültesi Dergisi. 2006;I3:438-46.

Balaban, Ö. ve Özdemir, Y. (2008)" Güirş̧imcilikEğitiminin Girişimcilik Eğilimi Üzerindeki

Büyüköztürk, S. (2007), Sosyal Bilimler için Veri Analizi El Kitabı, Ankara: Pegem A Yayıncilik.

Büyüköztürk, Ş. (2012).Sosyal Bilimler İçin Veri Analizi El Kitab1. Ankara: Pegem Akademi. Büyüköztürk, S. (2002)Faktör analizi: Temel Kavramlar ve Olçek Gelistirmede Kullanımı. Kuram ve Uygulamada Eğitim Yön Yönetimi Dergisi. 2002;32:470-83

Büyüköztürk, Ș. Veri Analizi El Kitabı. Ankara: Pegem yayınları, 2005, 5. Bask1, 1182.

Büyüköztürk, S., Cokluk, Ö., \& Köklü, N. (2009). Sosyal "bilimler için istatistik. Ankara: Pegem Akademi Yayıncılık

Cantillon, Richard. [1755] 1959.Essai sur la Nature du Commerce in Général. Henry Higgs, ed. and trans. London: Frank Cass. Third edition (2001), Introduction by Antony Brewer (New Brunswick, N.J.: Transaction Publishers)

Demirel, E. T. ve Tikici, M. (2010) Universite Ögrencilerinin Girișimcilik Özelliklerinin Beyin Baskınlık Analizi İle Değerlendirilmesi Elektronik Sosyal Bilimler Dergisi. Cilt 9, Say1 32, 221-253.

Deniz Z. Psikometrik Ölçüm Aracı Uyarlama Ankara Universitesi Eğitim Bílimleri Fakültesi Dergisi. 2007; 40(1):116.

DeVellis, R. F. Scale Development Theory and Applications Second Edition. SAGE Publications International Educational and Professional Publisher, 2003; chapter 5: 6096.

Doğaner, M. ve Altụnoğlu A. E. (2010) "AdnanMenderes Universitesi Nazilli İktisadi Ve

Ekici E. Öğretmenlere Yönelik Bilișim Teknolojileri Öz-yeterlik Algısı Ölceğinin Geçerlik ve Güvenirlik Çalış̧ması. Pamukkale Üniversitesi Eğitim Fakültesi Dergisi. 2012; 31:53-65.

Ercan İ, Kan İ. Ölçeklerde Güvenirlik ve Geçerlik. Uludağ Universitesi Tıp Fakültesi Dergisi. 2004;30(3):211-16.

Erkuş A. Psikometrik Terimlerin Türkçe Karşılıklarının Anlamları İle Yapılan Isslemlerin Uyuşmazlığı.Eğitimde ve Psikolojide Ölçme ve Değerlendirme Dergisi. 2010;1(2):72-7.

Etkisi: SakaryaÜniversitesi İ̈BF Örneği". Girișimcilik Ve Kalkınma Dergisi, Cilt 3, Say1 2, 133-147.

Hisrich, R. D. \& Peters, M. P. (1995). "Entrepreneurship Starting, Developing and Managing A New Enterprise". Third Edition, Irwin Publishing, Chicago: Irwin
Hisrich, Robert. D. ve Michael P. PETERS (1998) Entrepreneurship (4th ed.). Boston: Irwin McGraw-Hill.

Hisrich, Robert. D.ve Michael P. PETERS (1989).Entrepreneurship :Starting Developing, And Managing A NewEnterprise, Homewood, IL: BPI, Irwin McGraw-Hill.

İdari Bilimler Fakültesiİșletme Bölümü Öğrencilerinin Girisimcilik Eğilimleri”, Organizasyonve Yönetim Bilimleri Dergisi, Cilt 2, Say1 2,103-110.

Kashisaz, S. and E. Mobarak, The Effects of Private Education Institutes in Providing Modern Financial Knowledge in Developing Countries. Journal of Humanities Insights, 2018. 02(04): p. 172-178.

Kilıç, R., Keklik, B. ve Çalıș, N. (2012). Üniversite Ögrencilerinin Girisimcilik Eğilimleri Üzerine Bir Araștırma.Bandırma IIIBF İsletme Bölümü Örneği. Süleyman Demirel Universitesi İktisadi ve Idari Bilimler Fakültesi Dergisi, C 17, S. 2, ss:423-435.

Kinicki, A., Williams, B. K. (2003)

Management, A Practical Introduction, New York: McGrawHill/Irwin.

Kirzner, I. M. (1973). Competition and Entrepreneurship, IL: University of Chicago Press. Chicago.

Kline, R. B., 2005. Principles and Practice of Structural Equation Modeling. New York: Guilford Press

Kurnaz, M., Yiğit, N. Fizik Tutum Ölceği: Geliștirilmesi, Geçerliği. Necatibey Egitim Fakültesi Elektronik Fen ve Matematik Eğitimi Dergisi (EFMED). 2010;4(1):29-49.

Lordkipanidze, M., Brezet, H. \& Backman, M. (2005). "The Entrepreneurship Factor in Sustainable Tourism Development". Journal Of Cleaner Production, 13:787-798.

Malhan S, Öksüz E. Sağlığa Bağlı Yașam Kalitesi Kalitemetri. 1-5. Bölüm:29-98. 12. Merkibayev,
Bekkozhanova, G., $\quad \begin{aligned} & \text { Seisenbayeva, } \\ & \text { Koblanova, A., Z }\end{aligned}$ Alikhankyzy, G. (2018). Oppositions in the conceptual and linguistic category of time. Opcion, 34(85-2), 116-148.

Mostafavi, S.M., H. Malekzadeh, and M.S. Taskhiri, In Silico Prediction of Gas Chromatographic Retention Time of Some Organic Compounds on the Modified Carbon Nanotube Capillary Column. J. Comput. Theor. Nanosci, 2019. 16: p. 151156.

Mostafavi, S.M., K. Bagherzadeh, and M. Amanlou, $A$ new attempt to introduce efficient inhibitors for Caspas-9 according to structure-based Pharmacophore Screening strategy and Molecular Dynamics Simulations. Medbiotech Journal, 2017. 01(01): p. 1-8.

Muhammad, K., The Effects of Electronic Human Resource Management on Financial Institutes. Journal of Humanities Insights, 2018. 02(01): p. 01-05.

Najibah, S., Policies and Administrative Problems Related to Divorce Women Regarding to their Financial Activities. Journal of Humanities Insights, 2017. 01(02): p. 99-106. 
Naresh, K. M. Questionnaire Design and Scale Development" Chapter 5. http://www.terry.uga.

edu/ rgrover/chapter 5.pdf adresinden 24 Aralık 2013 tarihınde ulaşılmıștır.

Negiz, N., Özdassl1, K., Özkul, G., Alparslan Ali M. (2009) "Girisimcilik Özellikleri ve Tipleri Açısından CinsiyetFarklılıkları: SDÜ IIBF Araştırması", UluslararastDisiplinlerarasıKadın Çalısmaları Kongresi Bildiri Kitabı I. Cilt, 247-257.

Örücü, E., Kılıç, Recep ve .Özer Yılmaz (2007) "Ünirisimerilik Eüilimlerinde $\quad$ Ärencilerinin Faktörlerin Etkisi",Girisimcilik ve Kalkınma Dergisi, Cilt 2, Say1 2: 27-47.

Patır, S. ve Karahan,M. (2010) “Girisimcilik Eğitimi veÜniversite Ögrencilerinin Girişimcilik Profillerinin BelirlenmesineYönelik Bir Alan Arastırması", Isletme ve Ekonomi Araştırmaları Dergisi, Cilt 1, Sayı 2, 27-44.

Ronstadt, Robert. C. (1984). Entrepreneurship: Text, Cases, andNotes, Lord Publishing.

Shamsipur, M., et al., Biotransformation of methyl tert-butyl ether by human cytochrome P450 2A6. Biodegradation, 2012. 23(2): $\mathrm{p}$. 311-318.

Shane, Scott ve S. Venkataraman (2000) "The Promise OfËntrepreneurship As A Field Of Research", Academy of ManagementReview, Vol. 25, No 1, 217226.

Singh, A., \& Singha, N. (2016). ENVIRONMENTAL IMPACT OF NUCLEAR POWER: LAW AND POLICY MEASURES IN INDIA. Humanities \& Social Sciences Reviews, 4(2), 88-95. https://doi.org/10.18510/hssr.2016.424

Stevenson, Howard $H$. ve William A. Sahlman. (1989). "The Entrepreneurial Process", İcinde: DEWHURST P. B. J. (Ed.), SmallBusiness and Entrepreneurship, Basingstoke: Macmillan.

Stevenson, Howard. H., Roberts, Michael, Grousbeck J., Harold Irving I., ve Amarnaht Bhide (1985). New BusinessVentures And The Entrepreneur (2nd ed.). Homewood, Ill.: R.D. Irwin.

Tabachnick, B. G., \& Fidell, L. S. (2007). Using multivariate statistics. Boston: Pearson/Allyn \& Bacon.

Tavşancıl E. Tutumların Ölçülmesi ve SPSS ile Veri Analizi. Ankara: Nobel yayınevi, 1.bask1, 2002.

Tavşancıll, E. (2002).Tutumların Ölçülmesi ve Spss İle Veri Analizi, 1. Basım, Ânkara: Nobel Yayıncılık.

WICKHAM, Philip A. (2006) Strategic Entrepreneurship, 4thEdition, Essex, UK: Prentice Hall.

Yazdekhasti, A., Erfan, N., \& Nazari, N. (2015). Investigating the Relationship between Spiritual Intelligence and Social Adaptation among Girl High School Students in Shahreza City. UCT Journal of Social Sciences and Humanities Research, $3(1), 20-23$.

Y1lmaz E, Eser E. Miyokart Enfarktüsü T1p Eğitimi Dünyası / Mayıs 2014 / Sayı 4049
Boyutsal Değerlendirme Ölçeği ...(MIDAS) Türkce Sürümünün Psikometrik Ozellikleri. Anadolu Kardiyoloji Dergisi. 2011;11: 386401 .

Yllmaz E. ve Sünbül A. M. (2009) "Unniversite Öğrencilerine Yönelik Girişimcilik Ölçeğinin Geliştirilmesi", SelcukUniversitesi Sosyal Bilimler Enstitüsü Dergisi, Cilt 21, Say1 2, 195-203. 